\title{
Adult Education and Multirreferential Learning Environments
}

\author{
Ana María Casnati \\ Centro Universitario de Tacuarembó, \\ Universidad de la República, Uruguay;
}

\begin{abstract}
The research presented here is developed in a multireferential learning environment corresponding to the Youth and Adult Education Space (ANEP CODICEN) in Tacuarembó. The objective is to know the reality and the context of the people who attend these Spaces to contribute to the improvement of their quality of life, enhancing their personal and professional development, using telematic mediation. Also understand the reasons why adults decide to become literate, research and systematize about the interests and needs of adults regarding educational activities involving ICTs and contribute to knowledge in the area of adult education in Uruguay. To do this, a survey of data on the Spaces in the country and action research in Adult Education Spaces in Tacuarembó is carried out, using a qualitative-quantitative methodological approach. This allows characterizing the program assistants using participant observation, semi-structured interviews and life histories. It is verified that socialization and learning is the main motivation for the concurrence to these Spaces. In the interior of the country the classes have a profile of primary education while in Montevideo they work with a modality of manual and / or play activities. The profile of the teacher influences the pedagogical proposals but the assessment of the attendees is positive since many students after having passed the exams exam decide to continue the learning process.
\end{abstract}

Keywords: Adult Education, literacy, Multirreferencial Learning Environment

\section{INTRODUCTION}

In Uruguay, adult education recognizes the Constitution of the Republic and the General Law of Education (№ 15.739) as the general legal framework. This law was created when it was recognized that the country has a $4.3 \%$ of absolute illiteracy, since almost all children between 6 and 14 years old attend school, with a relatively homogeneous culture and a predominantly urban population. Until 1991 Adult Education was in the jurisdiction of the Primary Education Council, mainly attending what was called literacy education. Noticed the importance of renewing it and in response to the need for permanent self-development of the human being, understanding that it cannot be considered in itself but as a subset integrated into a general project of permanent education, the Central Steering Council of the National Administration for Public Education creates in February 1992 (Res. 1 Act. №9 of 02/12/92) the General Directorate of Adult Education, as the governing body of this educational area. Consequently, the purposes and tasks of the Directorate of adult Education, dependent on the National Administration for Public Education and the Central Steering Council of the mentioned Administration (ANEP CODICEN) are defined as follow:

a. Provide a second educational opportunity, be in literacy or in basic education

b. Allow the integration of the adult student to the community and the values that sustain it.

c. Facilitate the acquisition of basic instruments (knowledge, abilities, and skills) for its insertion or reinsertion in the labour market. 
In 2006, in relation to statistical data Uruguay's illiteracy rate was 2.2 in the urban area and 3.0 in the rural area (Source: Divulgación Preliminar Encuesta Nacional de Hogares Ampliada. Condiciones de vida de la población residente en el área rural. Enero-marzo 2006. Instituto Nacional de Estadística). However in locations of 5.000 inhabitants, $12.7 \%$ of the population fails to complete primary education and this is related to the problems of geographical inequality that the country presents.

When analyzing by age groups, the percentage increases with the age. Between 15 and 19 years, 3.6\% do not finish school; between 25 and 29, 3.4\% fail to graduate from primary education; between 40 and 44 years, $5.6 \%$; between 50 and 54 years, 10.2\%, and among adults of 80 and over, $42.2 \%$ did not finish primary school. These percentages coincide with the observations made in this research, where $80 \%$ of the attendees are over forty.

From 2007 projects like: “En el país de Varela: Yo sí puedo” (In the country of Varela: I can do it) are generated; it is a socio-educational program that is carried out through an agreement of the Ministry of Social Development (MIDES) and the National Administration for Public Education (ANEP). This program is originated in response to a need that is evident during the survey of households aspiring to the National Attention Plan for the Social Emergency (PANES), in which acquires relevance the worrying formal education level of young and adult people.

Fontes (2015)[1], when reflecting on the topic of adult literacy, states that research is scarce or null in aspects such as practices, methods, plans and programs, and the needs that are generated. He also argues that the methodological aspect is not addressed and the integration of new technologies is scarce (ICTs). This coincides with Yuni and Urbano (2005)[2] who characterize the theoretical basis of adult education research as "a conceptual dessert" and others like Cross (1981)[3] argue that is practically "non-existent".

Therefore this research responds to the need of observing an educational policy that is identified with the liberation of the subject in the Freirean sense of the word, differentiating it from educational policies based on hiding the real need of the subjects, in the fragmentation of literacy policies as a solution to the problem of the subject and in the determination of its role in an increasingly globalized society. It is interesting to know the development process of the subject who learns as a citizen and his training as an actor against the dominant market system.

For this, the objective is to know the reality and the context of the students that attend the Youth and Adult Education Spaces (ANEP CODICEN). It is recognized that is necessary to understand the reasons why adults decide to become literate, to inquire about their interests and needs regarding educational activities that involve Information and Communication Technologies (ICTs), specifically in Tacuarembó, and contribute to the knowledge in the area of adult education, especially in Uruguay. In this way, it is possible to collaborate to improve the quality of life of adults enhancing their personal development through digital literacy. The suggested hypothesis holds that adults, who have difficulties to reinsert themselves into formal education, when they incorporate telematics mediation, they are motivated and excited to continue studying and learning.

In the course of the research, some conceptual contributions on Adult Education and literacy are presented first. Then the Multirreferential Learning Environments (MLE) is described, specifically in the University Center of Tacuarembó (UCT) and the research methodology is detailed. Under the subtitle "Learning, artifacts and interactivities" the data collected at 
national level, from the quantitative point of view, are presented in order to provide an overview of adult education in Uruguay for the years 2012, 2013 and 2014. Then the qualitative analysis of the learning process of adults in Tacuarembó contributes to the understanding of the reasons why adults decide to become literate. Finally, in the conclusions a transversal logic is adopted which allows to identify certain strengths and opportunities offered by the MLE to meet the objectives proposed.

\section{CONCEPTUAL CONTRIBUTIONS}

Regarding adult education and its need for literacy, the discussion about what is true literacy is no stranger to international organizations like UNESCO. Starting with the LAMP project (Literacy Assessment and Monitoring Program) UNESCO proposes the analysis of the literacy level of the subjects considering five skills that are known through a specific test. The results of the studies, developed within the framework of this program, determine a categorization of the population in five typologies: completely illiterate, semi-literate, level of basic skills, level of average competences and level of skills in literacy that allows self-learning.

According to the experience developed, in educational activities in the northeast of Uruguay, having a study of this type, surely, the illiteracy band would be extended. In any case, adult education constitutes a relatively new social and cultural phenomenon. It can be stated that it dates back to the mind-nineteenth century because it is the result of a convergent process of social and cultural changes. But also, when beginning to apply the idea of lifelong learning, the concept of adult education acquires a new meaning. The first book in English that directly mention a special field called Adult Education is "The History of adult Education" by J. H. Hudson [4], published in London, in 1851. Then, Dr. Thomas Pole [5] publishes: "A History of the Origin and Progress of Adult Schools" in 1864. Thus, the field of adult education begins to take shape in the mind-nineteenth century.

Two theories emerge relevant to discuss the education of adults: the Theory of Human Capital and the Theory of the Filter (Yuni, A. and Urbano 2005). The first of these theories becomes one of the main foundations of the educational expansion experienced in the fifties and sixties, emphasizing the close relationship between education and economic growth. The Theory of Human Capital points out the relationship that seems to exist between the education of adults and the increase of productivity. The idea is that the education of adults leads to a better salary because it develops skills and increases the capacity of the worker group to develop their work efficiently. While for the Filter Theory the purpose of adult education is not so much to train workers to improve their productivity but to select them according to their abilities. In this way, the education of adults is not only seen as an investment, but as a reward. This theory holds that the education of adults has a positive effect on productivity since it is possible to identify the right people for the right job.

With the emergence of the New School in the late nineteenth century in Europe, there is a break in the educational matrix of traditional education to propose that the methodologies and teaching procedures need to take into consideration the characteristics of the trainees, paying particular attention to their interests. This vision is perceived in the educational proposal of the ANEP CODICEN where "regular modalities and flexible modalities are proposed, all with the aim of responding to the needs of people and the demands placed on them by the advancement of society" (http://www.anep.edu.uy/anep/index.php/direccion-sectorial-deeducacion-de-adultos-3). In turn, in today's learning society (Burnham, Rozo, Casnati, 2011) technological objects constitute artifacts that condition new ways of learning, organizing and producing knowledge (Gros, 2008)[6]. 
According to Mc Clusky (1971)[7] the needs that lead an adult to be educated can be systematized in the following way:

1. Need for adaptation: adults and especially the elderly need to meet certain needs to survive, adapt to the demands of an increasingly technological world and function satisfactorily in a complex and perpetually changing context.

2. Needs of expression: Adult Education favors participation, creativity and the development of skills and abilities that express the inner world, sensitivity and history of the elderly.

3. Needs of contribution: a commitment or responsibility is perceived by adults to contribute in some way to society as a whole.

4. Needs of influence or of provoking social changes: in the family environment older people usually look for information to influence the other generations through the exercise of their roles as grandparents.

5. Needs of transcendence: or need to better understand the meaning of life. This need may be present throughout life, but it may be very marked in the elderly.

Andragogy is a specific disciplinary field that deals with adult education and learning, and the andragogic knowledge, by teachers who teach adult education about the needs that motivate them to be educated, is of vital importance because it guides the design of the educational proposal. From this point of view, the following guidelines are presented:

- The person needs to take responsibility for his learning process. He learns because he wants to acquire knowledge that will help to transform his personal and social situation.

- The interests and needs of adults are related to the economic, political and cultural aspects of the context to which they belong. Learning is recognized as a process of formation throughout life and this is closely related to the use of technological devices and the consequent improvement of the economic and social level.

- The permanent confrontation between theory and practice, and the analysis of the process is an important aspect of the andragogic process, forcing teachers and apprentices to develop their critical and innovate activity. This process is produced and verified in the present investigation.

- The educational institutions that design and develop andragogic processes hold the responsibility of creating and recreating values towards socially useful work.

The Multireferential Learning Environments, in Tacuarembó, which work with the Adult Education Spaces travel along this road.

\section{MULTIREFERENCIAL LEARNING ENVIRONMENTS}

The environment can be defined, according to the dictionary of the Royal Spanish Academy, as "a compendium of social, natural and cultural values existing in a place, at a given moment, that influence the material and psychological life of the human being". The environment appears as a result of the interaction of the subject with its environment and can be classified as a dynamic concept based on relationships with knowledge. The subjects who learn are able to reflect on their own action as well as on that of others, in relation to that environment that circumscribes them. In this way, the environment transcends the idea of physical space and involves various relationships configured as a space of significant culture construction. For Ospina (1999)[8] this means that the environment can be considered as a daily construction, daily reflection, and permanent singularity that ensures the diversity and richness of life. 


\section{Meaning the multireferenciality}

Ardoino (1999)[9] considers multireferenciality as a proposal that contributes to overcome the difficulty of understanding the complexity of reality from an approach that recognizes the heterogeneous nature of the object of the analysis process. The heterogeneity of social phenomena, as the process of learning adults, in a given context, is noticed when observing the evolution of contemporary society, reason why the combination of different perspectives is necessary, the contribution of different disciplines to answer questions and interpret the phenomena, avoiding homogenization and reduction in understanding. Concomitantly social relations, aesthetic, emotional and affective expressions are included in addition to the biological, economic factors that reflect the socio-historical-cultural conditions of the subjects and social groups.

Consequently, in the Multireferential Learning Environments (MLE), symbolic, cultural, ethical, political and pragmatic perspectives intervene explicitly or implicitly, among others, which are not subject to the logical and methodological foundations of the disciplinary schemes.

\section{MLE in Tacuarembó}

Since 2013, in the University Center of Tacuarembó (UCT) a group is constituted and integrated by students from different disciplines and institutions of tertiary education, guided by a teacher. This group seeks to learn, to accompany and to take advantage of the community experiences in order to generate opportunities for reflection that will facilitate the understanding of the complex reality. In this specific case the Spaces of Adult Education ANEP CODICEN are developed in Neighborhood Centers 1 and 3 of the same city. Therefore, the multireferentiality is favored as a result of the integration of groups of students and teachers with different disciplinary knowledge and training.

As a result of the interactions between university students and teacher training, students of the spaces, professors and teachers, an intentional articulation is perceived between learning processes in the broad sense of immaterial production of knowledge, development of personal and professional competences, creation of alternatives to solve everyday problems and work both in production and in the reproduction or reuse of material goods and services. In this MLE it is recognized the value of information/knowledge and its consequent demands in the sense of access, availability of information, as well as the production of meaningful knowledge.

In these environments intensive learning activities are carried out through processes of production/exchange of knowledge/practices, dissemination of information, development of techniques and technologies, construction of ethos, ethics and aesthetics meaningful for the communities involved. The MLE can be concrete and/or virtual and the knowledge is deciphered, decoded, translated, shared, understood, and internalized for the construction of subjectivities and culture. Thus, the spheres and dimensions of social life are expanded and taken as a basis for this interaction with knowledge.

Guattari (1985)[10] differentiates space from territory recognizing in the space certain planned, projected and programmed functions. The territory, in terms of materialized spatiality, is defined from subjective relationships -he called them "territories of subjectivation or existential territories". In the present essay the word "environment" indicates the relevance of technological mediation as a facilitator of all the aspects indicated where the idea of territory (Guatari) acquires special relevance. In this way, the technological mediation in a MLE does not refer exclusively to the artifacts or tools used (ceibalitas: notebooks) but to the modes of perception and language, narratives, writings and sensibilities that configure the subjectivities of the people involved. 
Taking into account this conceptualization the activities, developed by the MLE in Tacuarembó (2013/2016), generate different products:

- Publication of a handbook "Conviviendo con la Diabetes" (Living with Diabetes) using the applications "Escribir" (Write) and "Paint". This book is distributed in all the public libraries of Tacuarembó, in 2014.

- Video where is shown part of the creation of comics using the Scratch program made by the members of this investigation in the scenario of the Neighborhood Center № 1 , Ferrocarril Neighborhood in 2015. (https://www.facebook.com/FlorDeCeiboEnTacuarembo/posts).

- Publication of a book with life stories of the participants in the Space of the Neighborhood Center № 2 in 2016 written by them. This proposal contributes to recognize the language as a vehicle of construction and affirmation of cultural identity, to link language with experience, to value writing and reading as an instrument of individual and social development stimulating the habit of written communication by mastering the techniques for its realization. In spite of the difficulties that an endeavor like this entails, with will, joy, solidarity and rigor a publication is obtained and manifests the desire to learn proper and appropriate for citizens of Tacuarembó.

\section{METHODOLOGY}

The multireferential approach does not pretend to exhaust the study of a multidimensional process where its opacities are recognized and then, its complex nature. Therefore, this research adopts a complex, interpretative, critical and transformative perspective that requires constant reflection on the practice to know and understand the context of the adult students, from the point of view and sense that the participants of the MLE give to it. When developing the methodology a methodical, inductive process is respected, where situations are intertwined, from an approach that privileges the interests of adults with respect to educational activities involving ICTs. Thus the research methodology, in the MLE, has been:

- Participant observation, field diary, reflection and registration workshops according to pre-established and agreed guidelines to know the reality, context and interests of the people who attend these Spaces during the years 2013, 2014, 2015 and 2016 in the Education Spaces of Adults in Tacuarembó.

- Bibliographic research to deepen knowledge and understand the state of the art on Adult Education made in the MLE in 2014 and 2015.

- Survey of statistical data on Adult Education in Uruguay, carried out in the MLE during 2014 and 2015, which contributes to know the reality of these environments at a national level.

- Research, action and participation based on collaboration, decision making in a democratic and consensual way, and technological appropriation based on critical reflection. This critical reflection has been generated in the activities and in the evaluation processes.

Definitely, it is about to generate a deliberate action to transform reality and produce knowledge of those transformations produced. Thus, mediations form networks of meanings, not only contextual but intertextual where by confluence they are manifested, mobilized and linked. As a result, an authorization process takes place and the group becomes the author of complex situations in the course of praxis where conflicts and unforeseen situations generated by technological and institutional difficulties are handled.

Another characteristic of the research-action is the "sensitive listening" (Barbier 2007)[11] that consists of perceiving, seeing, and sharpening the ear to understand, being attentive in all directions, when a silence arises or when someone takes the floor. This sensitive listening is 
based on empathy, understanding the affective and cognitive imaginary of the course assistant: his attitudes, behaviors, systems of ideas, values and symbols. It is necessary to appreciate the differential place that each subject occupies in the field of relationships, to understand his words and his creative capacity. The attitude required for a sensitive listening is a holistic opening where the presence of the other is felt with its imagination, its reason and its affection in permanent interaction. In this way, a network of discursive practices is produced that constitute mediated actions, where the process of communicative interaction is installed. It is, thus, a diverse, complex process in which transformations occur and shoot in different directions, and where multiple connections coexist.

LEARNING, ARTIFACTS AND INTERACTIVITIES: DISCUSSION AND ANALYSIS IN THE MLE The analysis and reflection on the results in the MLE are made as the learning process progresses, based on the collected data and the characterized products. In this way, at the end of the process, different levels of analysis are identified. In the first instance is examined and recorded an analysis of the statistical data collected at national level; then another level that refers to the qualitative analysis of the learning process of the adults attending the spaces in Tacuarembó; finally, a third level that refers to the praxis of university students in MLE and the teacher relations.

\section{Processed Statistical Data}

According to the data collected, it is noted that in 2014 the number of students enrolled in the spaces in the inland of the country increased in relation to 2010 . This can be seen in graphs 1 and 2. Graph 1 (2010) shows that of a total of 6.993 enrolled, 27\% of the students belong to the inland and $73 \%$ to Montevideo. Taking into account that the call for adults is made on demand, highlights the increase of interest in the ongoing process of education by the adult population in the country.

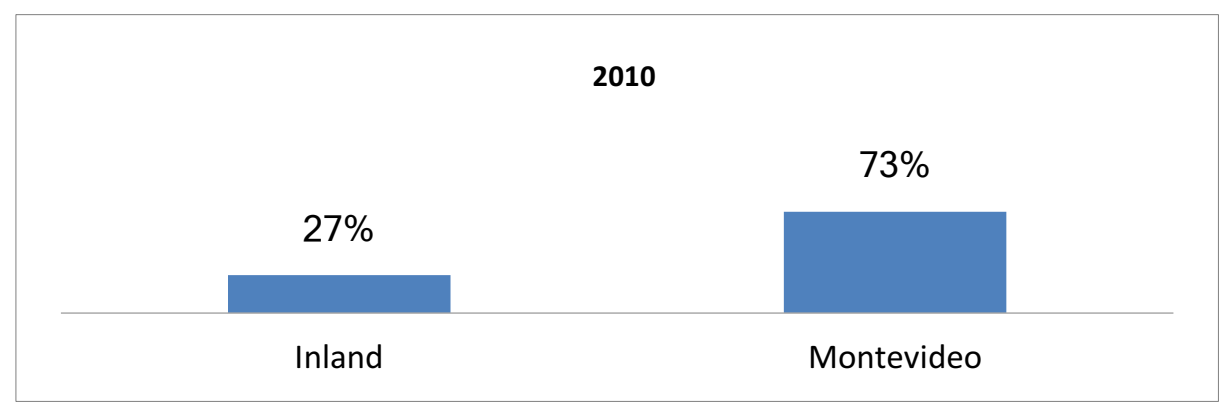

Graph 1- Comparative statistical data Montevideo - Inland, year 2010 (Source: ANEP CODICEN)

Graph 2 shows that in 2014 the total number of registrants reached the sum of 7.813 people, of which $59.30 \%$ are students who attends workshops in Montevideo. In the inland what stand out is the modality of students in primary education with a $40,70 \%$. 


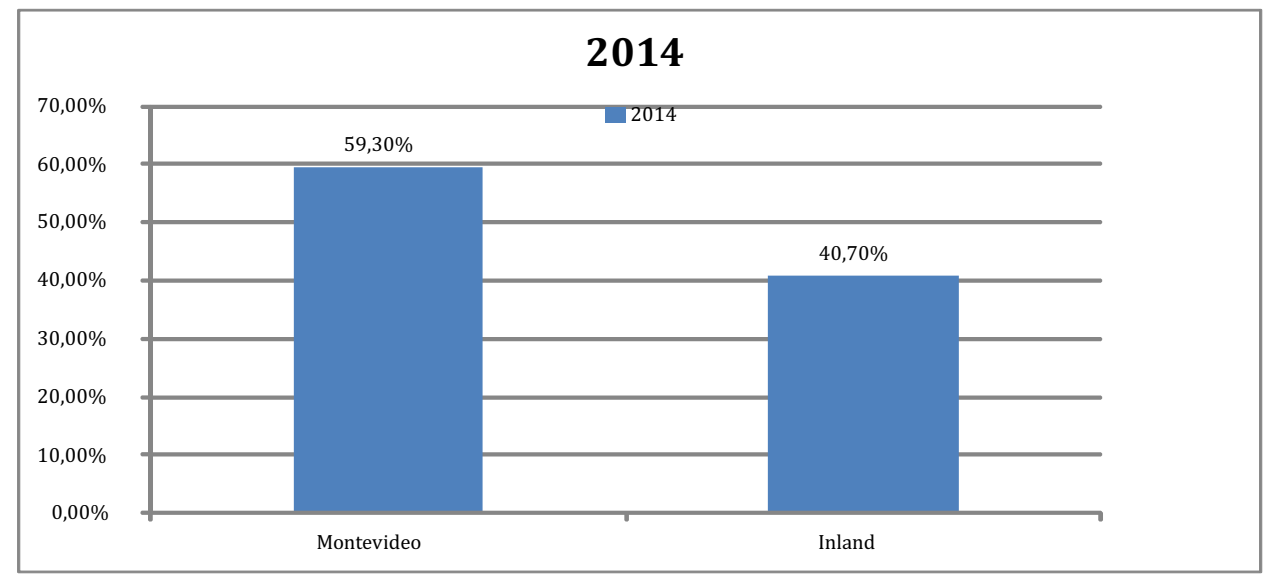

Graph 2- Comparative statistical data Montevideo-Inland, year 2014 (Source: ANEP CODICEN

Table 1 and Graph 3 show the number of participants in the Spaces in the country per year $(2012,2013,2014)$ in the two modalities (workshops or primary) and in the accreditation tests; the average number of participants is maintained in each modality. Table 2 shows the distribution of the population that attends the spaces in Uruguay by age and sex (2014); as the ages increase, the participation of women increases. The analysis of statistical data shows a gender inequality that is also found in the qualitative study since women are late integrated into the Spaces, after they manage to "liberate themselves" in part from the multiple domestic and family tasks.

\begin{tabular}{|l|c|c|c|}
\hline & $\mathbf{2 0 1 2}$ & $\mathbf{2 0 1 3}$ & $\mathbf{2 0 1 4}$ \\
\hline Primary & 3.234 & 3.136 & 2.980 \\
\hline $\begin{array}{l}\text { Proof of } \\
\text { accreditation }\end{array}$ & 1.154 & 1.151 & 1.207 \\
\hline Workshops & 4.291 & 4.065 & 3.626 \\
\hline $\begin{array}{l}\text { Total enrollment } \\
\text { per year }\end{array}$ & 8.679 & 8.352 & 7.813 \\
\hline
\end{tabular}

Table 1 - Comparative data of students in the period 2012-2014

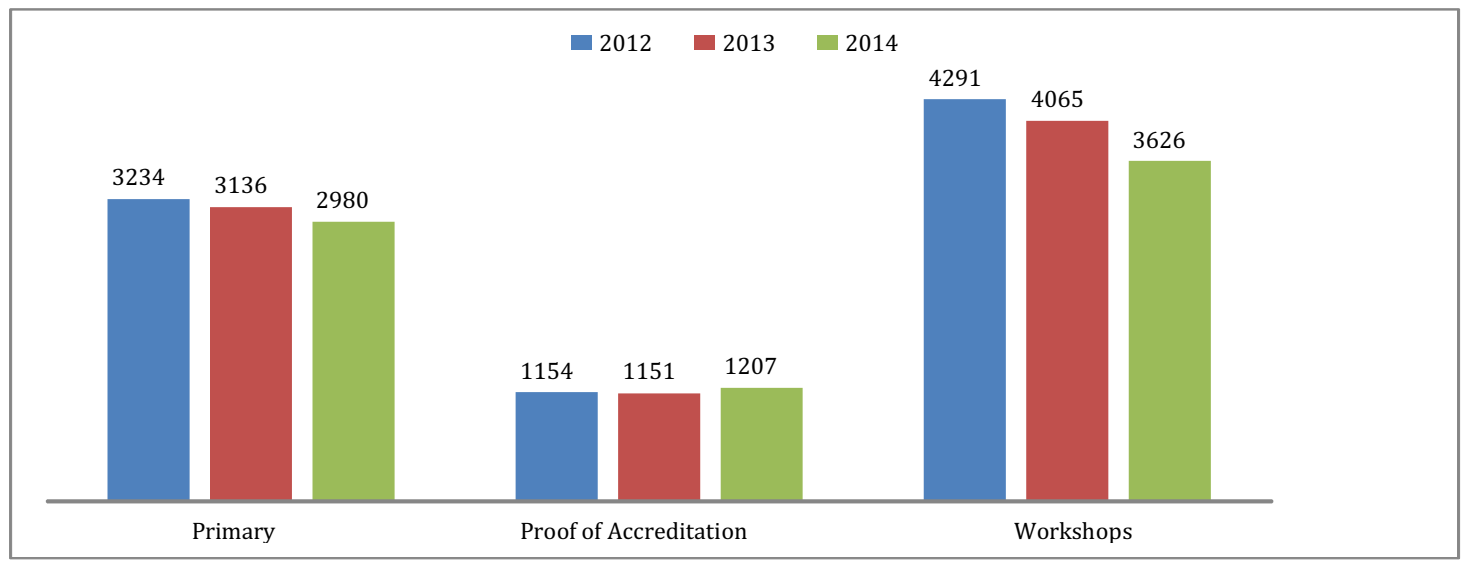

Graph 3 - Comparative data of students in the period 2012-2014 (Source ANEP CODICEN) 


\begin{tabular}{|c|c|c|c|}
\hline Ages & Men & Women & Total \\
\hline 14 a 17 & $14,9 \%$ & $13,1 \%$ & $28 \%$ \\
\hline 18 a 29 & $12,4 \%$ & $11,1 \%$ & $23,6 \%$ \\
\hline 30 a 50 & $12,2 \%$ & $19 \%$ & $31,2 \%$ \\
\hline $\begin{array}{c}\text { More than } \\
50\end{array}$ & $4,3 \%$ & $13 \%$ & $17,3 \%$ \\
\hline
\end{tabular}

Table 2 - Distribution by age and sex of those registered in 2014 (Source ANEP CODICEN)

\section{Qualitative analysis of the learning process of adults attending the spaces in Tacuarembó}

The main motivation for the concurrence of adults in the Spaces is the need to socialize and learn. This is reflected in the story told by a student in 2014:

"I am M.T. I'm 69 years old, I live 5 blocks from El Hongo. I was told that in El Hongo classes were taught; I introduce myself and I loved the group. I also like the teacher and my classmates who encourage me to continue. I feel satisfied because I am learning and I plan to continue".

By producing a handbook "Conviviendo con la Diabetes" (Living with Diabetes), in 2014, in the MLE adult learners and university students are forced to continually redefine communication, which involves redrawing radically their relationships with knowledge and the domain of nonverbal and affections. The most significant practices are defined in the nonverbal domain and that which exceeds the logos (music, visual arts, and culinary arts). In many respects, the relationship is characterized mainly by the use of verbal language but even more by the plurality of specific forms of nonverbal thinking and communication that are articulated in mediation. This can be seen when observing photograph 1.

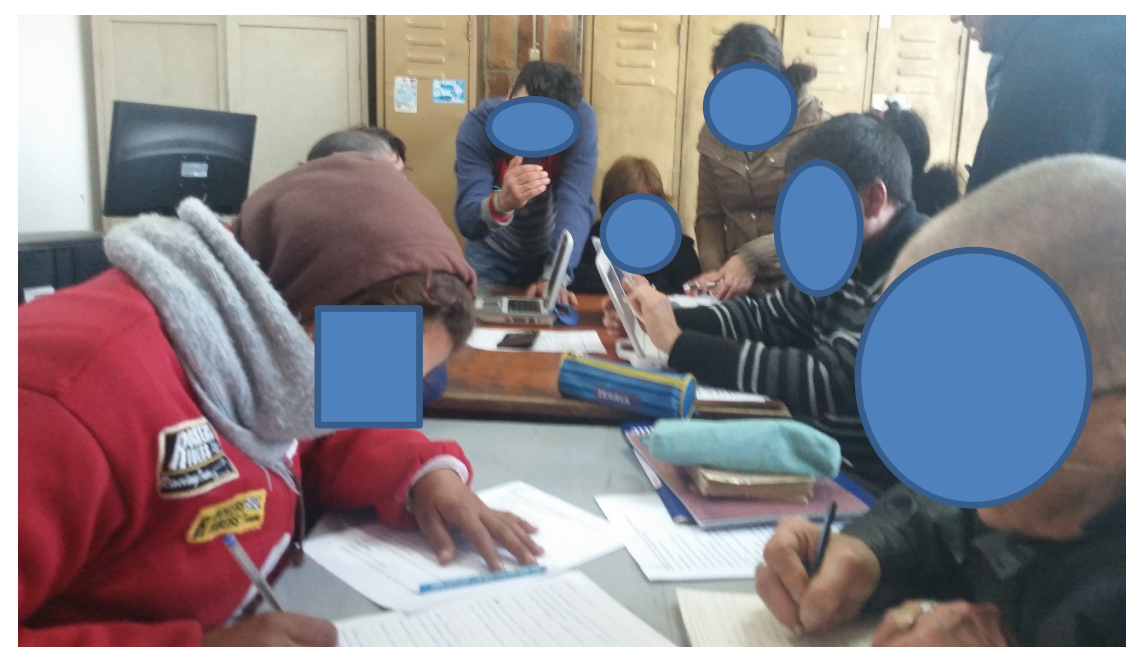

Photography 1 - Multireferential Learning Environment in Tacuarembó, 2016(Author font)

"I am S., I'm 35 years old, mother of B. who is 16 years old, and A. of 10 years old [...] I work with my brother Pablo bringing the documents to the account. I'm finishing primary school in the neighborhood center $N^{\circ} 3$. I came here because when I was a child, school age, my parents decided that my brother, who was oldest, would study and I went with them to the country (History of Student 2015)". 
From the previous story it emerges that in the power relations the material inequalities of the students of the Adult Education Space are intertwined with a non-material inequality, especially with an unequal education often manifested by them in the stories in the MLE.

"I lived in the countryside and my parents said that a girls does not need to study, the woman is to stay at home raising the children" (testimony of a student of 65 years, 2015).

"My family consists of my parents, my brother and me. As money wasn't enough to send both of us to study, my parents preferred my brother to study and now he is an engineer while I could not finish sixth of school. (testimony of a 32 year old student who explains her situation without expressing any problem, as if the failure to complete primary education were a natural consequence of her condition as a woman, 2015)"

"Here, I am happy because I feel valued; in my house they tell me that I am not good for anything. (Testimony of a student of 40 years, 2015).

These testimonies show unequal forms of education but also reveal inequalities in abilities, communicative and expressive representations, as well as inequality of opportunities to participate autonomously in processes of subjectivities that require significant decisions in order to develop with a proper and appropriate life.

In 2016, the proposal of the adults arises from a felt need in the group to write the life stories using the XO tool. So, we have a text that is the product of an arduous task, a process of composition, of putting into practice a series of strategies that allow adults to express themselves and communicate something through writing. Writing the history of life, favored by the use of ceibalitas (notebooks), requires time and effort; it is necessary to create communicative environments in which the intentionality of transmitting their interests is manifested, promoting their personal development. In the process of literacy mediated by the $\mathrm{XO}$ it is necessary to look for the right words, shape the thought, order and make explicit the ideas that are to be communicated. The writing process (prewriting, writing and rewriting) is recursive. The adult plans, does, remakes, plans rewrites and corrects constantly. Simultaneously cognitive processes are activated such as selecting, classifying, generalizing, sequencing and as a result there is a text like the following:

"I'm A.F.R., I am 23 years old and the first thing I remember is that I was going to school at level 5 with teacher Susana. I did not like my mother's personality because she was bad with me, she beat me for fun, and she would run me at any time and leave me without food all day. My father was good, he did not hit me and he fed us; he was humble and respectable person. He worked and did not bother anyone. My mother was arguing with my father and my father, calm and patient, expected my mother to get tired of arguing. I did not share many moments with my family [...]. My childhood was the worst thing in my whole life because my mother always beat me. [...] My occupation was to wash clothes outdoors in a container near the river at 10 years old every 15 days. They never had time to take care of me. The nice thing was that my friends, when I needed them, they were with me and we played hopscotch. The most beautiful thing was to raise my daughter although I could not finish $6^{\text {th }}$ grade of primary. I went to school until [...] until I was 14 years old because then I got pregnant of my daughter and they ran me. And now I intend to finish primary to continue studying and working as an auxiliary nurse". 
In this way, the lives of adults are reconstructed in part from an account of their own existences, basted afternoon to afternoon facing the difficulties of use of the ICTs that result novel and intriguing. The final product is a coherent narrative written where in the MLE the research takes a course of biographical cut and where the singular modes of learning of each member are respected.

\section{Praxis of the university students in the MLE and teacher relations}

To work on this research, the students of the University Center of Tacuarembó and the Teacher Training Institute had to put into play four procedural skills: observe, listen, compare and write, as Sanmartin (2003)[12] proposed when referring to the practice of qualitative research. These skills are specified in a work that also requires systematization and a certain dose of craftsmanship. At the beginning the activities of the university students are mediated by the teachers who work in these Adult Education Spaces, guided by the UCT teacher and also guided by intuition, without strong theoretical support. A student describes that:

"Work with adults supposes to generate particular socio-affective conditions. It is important to build bands and trust with them, be kind without leaving aside the requirement that involves a learning process. At the beginning of each activity we made a review of what was previously given and we highlighted the most important thing. At the beginning the interventions, in the development of the proposals, needed a follow up and support of the group [...] because the adult was becoming familiar with the computer of the Plan Ceibal, but as time passed [...] the activities were carried out without major difficulties, with greater autonomy, reducing our support only when they demand it. [...] the selection of contents is adapted to the interests and needs of the apprentices".

Through this brief description it is perceived that the students, in the MLE, feel more and more involved in understanding the changing situations in a multi-referential social context, using ICTs as artifacts of learning. Learning means to participate in a shared responsibility, to contribute to the learning community, which requires an ability to use technology to learn together, collaborate, share and transfer. The proposal of MLE aims to a collaborative and participatory learning mode. The stories of adults reveal socio-political micro devices of power and their expressions, which make up discourses, allow us to understand the problem of the "exclusion" of adults in this production of discursive practices.

Sousa Santos (2011)[13] defines power as a social relationship regulated by unequal exchanges and its power lies in the ability to reproduce inequality in situations that determine actions, projects and experiential trajectories as well as resources, services, symbols, values, identities, abilities, opportunities, aptitudes and interests. Faced with these situations, in the MLE, students learn to consider the inequality of an unequal exchange and to evaluate to what extent that relationship is determinant; it affects the living conditions and the trajectory of the apprentices. They understand that power relations are not isolated relationships; on the contrary, there are chains, networks that extend, extend and expand in a patriarchal society, of capitalist exploration where the market dictates fetishistic patterns. This conditions an ethical position of respect, affection and empathy.

Regarding the teacher, a pedagogical flexibility is required, which demands a capacity to expand and enrich the way of learning through an experience with new models and forms of creation, design and construction of knowledge. This pedagogical flexibility is understood from the ignorance that is not disregard or pretend. It is about perceiving the learning that in the MLEs astonish, move and modify the life of each member. In the learning process, when interacting with different teachers, it is perceived that the teaching profile influences the 
pedagogical proposals and the behavior of the adult group. In the city of Tacuarembó there are teachers in charge of these Spaces who care about imparting school curricular knowledge and others, willing to work based on the interests of their students.

\section{CONCLUSION}

The present research aims to know the reality and context of the students who attend the Youth and Adult Education Spaces (ANEP CODICEN). It is recognized that is necessary to understand the reasons why adults decide to become literate; inquire about their interests and needs regarding educational activities that involve Information and Communication Technologies (ICTs) specifically in Tacuarembó, and contribute to knowledge in the area of education of young people, especially in Uruguay. In this way it is possible to collaborate to improve the quality of life of adults, promoting their personal development through digital literacy.

In the conclusions a transversal logic is adopted that allows, from the perception of certain continuities and discontinuities to recognize the fulfillment of the objectives set. Thus, in the MLE, research can be understood as an attitude of life, a component of scientific production and education, in particular of critical and creative questioning. This condition is at the root of all emancipatory process, assembling wisdom and change in the learning process. In the MLE, the technological domain is not reduced to the technical-formal competence since it manages to include answers to the question of "for what and for whom". If we understand education as emancipation, "learning" can be overcome by "learning to learn". The capacity of technical application is fundamental, but it does not substitute the general information that allows the theoretical dominion of the processes and the constant critical questioning that the MLE promotes. This shows that education formalizes its humanist position because, when understood as theory and practice of the integral development of human beings and permanent creative social capacity, it cannot be oriented solely to the technological challenge. The technological domain is part of the emancipation, but it is only a part, it is also necessary to consider the formation of the social subject as a citizen from an eminently political approach. The debate on technology leads to the questioning of everyday situations in order to assess what is relevant, timely, inevitable in the use of ICTs in education and this is part of the digital literacy process. The conclusions developed below reflect a "dynamic objectivity" (Fox Keller, 1994, p. 143) [14] where the search for knowledge investigates subjective experience from an interest in the "most effective objectivity". This necessarily leads to an "embodied knowledge" situated, contextualized and radically connected with the environment.

After these remarks and in accordance with the fulfillment of the objectives it is highlighted that the state of the art on Adult Education in general and in Uruguay in particular shows that the literature on the subject is scarce and the field of research has still been little explored. The processed statistical data contribute to provide a limited but recent panorama of the population that attends these spaces of ANEP CODICEN as a result of an education policy for Uruguayan citizens for life. On the other hand, confronting the results and reflections of the action research in Tacuarembó and the spectrum of needs of Mac Clusky, there is a marked interest of the actors of the MLE for digital literacy. The testimonies of adults show the need to adapt to the technological demands of life to function satisfactorily on a complex and perpetually changing world. For this reason, they express their desire to understand and train in the use of the XO in order to participate and interact with their children, grandchildren and neighbors, who correspond to the need to contribute: giving something for the context where they live. That interest also responds to the needs of expression that impels them to produce two books and a video developing communication and skills to better understand the meaning of life. 
In spite of the difficulties posed in the learning process, sacrifice, discrimination, poverty and injustice they are represented in the stories, between lines or explicitly. This allowed to understand the context and reality of the actors in Tacuarembó, however the MLE integrated by the teachers and students of the UCT, constitute a refuge where it is possible to specify life objectives repeatedly postponed by more pressing demands than school learning. Each adult student who participates in the MLE is the protagonist of his learning process and expresses his irreducible will to continue learning, enjoying the company of his colleagues meeting every afternoon in the neighborhood center. Proposals such as the production of publications, which involve creativity, are very motivating and are taken as a challenge. For example, the programming with Scratch, the elaboration of comics, the production of the handbook " Conviviendo con la Diabetes" (Living with Diabetes) and the production of the "Stories of Life" have been call challenges for adult groups. Play activities are less interesting because students show greater interest in acquiring applicable knowledge in their daily lives. These statements allow us to understand the interests of adults regarding educational activities involving ICTs. Obviously the MLE has managed to enhance the personal development of its members using telematics mediation and has captured the reasons why adults decide to become literate. However, despite the opportunity to develop greater autonomy, adults often show themselves to be very dependent on the teacher and university students. These MLEs are highly valued by their participants because the adults interviewed after having finished and passed their exam, decide to continue the next year and repeatedly state the importance of learning throughout life. At the end of the learning process, the proposed hypothesis is confirmed: adults manage to learn, motivated by ICTs and that encourage them to continue, which improves their selfesteem. This is verified by manifesting changes in their attitude towards life, when they decide to continue studying to "know more" or to access "a better job".

As a result, the present research appears not only as an instrument of scientific production, but as an "educational principle" (Demo, 1990)[15], emerging at the same time on the basis of the formal and political quality of university education. Through digital literacy and interaction in the MLE, there is an appropriation and empowerment that results specifically from mutual influence as an ethical contribution. Research from a collaborative action promotes and mobilizes the potential of people for a better quality of life. The MLE in Tacuarembó assumes the commitment of its own production of knowledge in a context where reality is questioned. It is possible to recognize a personified power of knowledge of being, open and possible, a singular difference of the subjects in the MLE. This singularity is productive, self-valorizes the intrinsic capacity of each apprentice, exploring the multiplicity of possibilities through cooperation, transforming existence into an opportunity for freedom, autonomy and the construction of citizenship.

In the MLE, the possibility exists for teachers and students to be with the other from the essence of the word to share and the affectivity involves the cognitive process that is manifested in the testimonies and photographic documents. So the university function is resized in terms of participation and the concept of citizenship; where are practiced attitudes of learning to listen, to see, to speak and to describe the world with meaning. This is the strength of the MLE because they offer the opportunity to learn a contextualized knowledge.

\section{References}

Fontes, E. Desafíos de la educación de jóvenes y adultos de ayer y hoy. 2015 En

(http://ipes.anep.edu.uy/documentos/adultos/materiales/desafios.pdf), acces. 02.02.2017.

Urbano, C.A y Yuni, J.A. Educación de adultos mayores. Teoría, investigación e intervenciones. España: Brujas 2005.

Cross, P. Adults as Learners: Increasing Participation and Facilitating Learning. USA: Jossey Back Classics.1981. 
Hudson,J.H. The History of Adult Education . USA: The Classics. 2013.

Pole, T. A History of the Origin and Progress of Adult Schools, Bristol: Mac Dowall. 1890.

Gros, B. Aprendizajes, conexiones y artefactos. Barcelona, España:Gedisa. 2008.

Mc Clusky, H. Education: Background Issues. White House Conference on Aging, Washington, D.C.1971.

Ospina, E. Educar, el desafío de hoy: construyendo posibilidades y alternativas. Santafé de Bogotá: Cooperativa Editorial Magisterio. 1999.

Ardoino; J. Abordagem multirreferencial (plural) das situações educativas formativas. In: Barbosa, J. (Coord.). Referencialidade nas ciências da educação. São Paulo: UFSCar, 1998. p. 24-41.

Guattari,F. Caosmose: um novo paradigma estético. São Paulo: Ed. 34. 1985.

Barbier, R. A pesquisa-acao. Br. Liber libro Ed.2007.

Sanmartín,R. (2003) Observar, escuchar, comparar, escribir: la práctica de la investigación cualitativa. España, Ed. Ariel. 2003.

Sousa Santos, B. A crítica da razão indolente.S. P. Cortez Ed. 2011.

Fox Keller, E. La paradoja de la subjetividad científica. En Fried-Schnitman( Ed.) Nuevos paradigmas: cultura y subjetividad. Barcelona: Paidós. 1994.

Webgraphy.

ANEP-CODICEN. Memoria de gestión 2005-2014. (2014). Recovered from http://www.anep.edu.uy/anep/phocadownload/dsea/Informes_de_Gestion/memoria\%202005-2014.pdf UNESCO-UNICEF. (1994) La educación de adultos en América Latina ante el próximo siglo. Recovered from http://www.unesco.org/education/pdf/251_59.pdf

YouTube. Educación de Adultos. Recovered from https://www.youtube.com/watch?v=BMzo24eUgqM

YouTube. Flor de Ceibo CUT. Recovered from https://www.youtube.com/watch?v=cwZf2RXSsmg 